\title{
Microbial diversity along a transect of agronomic zones
}

\author{
A.M. Ibekwe a,b,*, A.C. Kennedy a, P.S. Frohne a, S.K. Papiernik b, C.-H. Yang c, \\ D.E. Crowley ${ }^{\mathrm{c}}$ \\ a USDA-ARS, 215 Johnson Hall, Washington State University, Pullman, WA 99164, USA \\ b USDA-ARS, George E. Brown Jr. Salinity Laboratory, $450 \mathrm{~W}$. Big Spring Rd., Riverside, CA 92507, USA \\ ${ }^{c}$ Department of Environmental Sciences, University of California, Riverside, CA 92507, USA
}

Received 6 August 2001; received in revised form 15 November 2001; accepted 16 November 2001

First published online 17 January 2002

\begin{abstract}
The diversity of microbial communities constitutes a critical component of good soil-management practices. To characterize the effects of different management practices, molecular indicators such as phospholipid fatty acid (PLFA), denaturing gradient gel electrophoresis (DGGE) and composition of ammonia-oxidizing bacteria were used to analyze bacterial community structure and diversity from four eastern Washington State soils. Samples from four sites were collected representing a transect of high-precipitation to low-precipitation areas that covered different agronomic zones with different management and cropping practices. Biomass amounts estimated from extractable PLFA were significantly higher in the no-till (NT) soil than in the conventional-till (CT) soil. Similarities among the different 16S rDNA DGGE band profiles were analyzed quantitatively using correspondence analysis and this confirmed that the CT soil was the most dissimilar soil. DGGE analysis of 16S rDNA ammonia-oxidizing bacteria from the four soils revealed two identical bands, indicating little effect of agronomic practices and precipitation on these species. A second set of primers, specific for amo A (ammonia monooxygenase) genes, was used to examine ammonia oxidizers in the samples. Six banding patterns (clusters) from amplified rDNA restriction analysis of 16S rDNA fragments were observed after restriction analysis with HinfI. Sequencing of these clones revealed the presence of only Nitrosospira-like sequences. Analysis of the sequences showed that ammonia oxidizers from the NT soil were more diverse compared to those from the CT and conservation reserve program soils. Our data showed that management and agronomic practices had more impact on bacterial community structure than annual precipitation. (C) 2002 Published by Elsevier Science B.V. on behalf of the Federation of European Microbiological Societies.
\end{abstract}

Keywords: Soil quality; Microbial community structure; Phospholipid fatty acid; Microbial biomass; Denaturing gradient gel electrophoresis; Ammonia oxidizers; and Ammonia monooxygenase

\section{Introduction}

Microbial communities are critical components of soil and may be the earliest predictors of soil quality changes [1]. A recent definition of soil quality is the ability of soil to sustain biological functions and promote plant and animal health [2]. The diversity of microorganisms in soil is critical to the maintenance of good soil health because microorganisms are involved in many important soil functions such as carbon and nitrogen cycling, soil tilth and structure [3], and organic-matter transformation [4]. Several microbial methods including the traditional ap-

\footnotetext{
* Corresponding author.

Tel.: +1 (909) 369 4828; Fax: +1 (909) 3424963.

E-mail address: aibekwe@usll.ars.usda.gov (A.M. Ibekwe).
}

proaches have been used to study microbial diversity in agricultural soils $[5,6]$. Recent developments in molecular biology and biochemical assays for soil microbial community structure analysis have provided new tools to conduct experiments on soil microbial components without using the traditional approaches.

The quantitative description of microbial communities is one of the most difficult tasks facing microbial ecologists, as the classical technique of viable counting recovers only a small proportion of cells [7]. At present, only two methods have overcome the problem of selective culturing and provide an unbiased view of the structure of complex microbial communities. These are (1) analysis of microbial populations using ribosomal RNA (rDNA) and (2) phospholipid fatty acid (PLFA) analysis [8]. Microbial community analyses using rRNA can detect and identify community members with high specificity to the species and 
strain level, and can also detect and suggest phylogenetic affinities of uncultured organisms [9]. PLFA can be used to quantify community structure and biomass without relying upon the cultivation of microorganisms. Unfortunately, this approach does not have the capability of identifying microorganisms at the species or strain level, but rather produces descriptions of microbial communities based on functional groupings of fatty acid profiles. This concept has resulted in the identification and quantification of viable biomass and community structure in sediments [10-12] and in agricultural soils [13,14].

Use of the 16S rRNA gene as an indicator for species diversity is providing a fresh approach for investigating the structure of microbial communities. Such methods include thermal and denaturing gradient gel electrophoresis (DGGE) $[15,16]$, terminal restriction fragment analysis [17-19], and 16S rDNA sequence analysis [20,21].

One of the critical functions of soil microorganisms in maintaining good soil health is the cycling of nitrogen. This process is carried out in part by ammonia-oxidizing bacteria. This group of bacteria is responsible for the conversion of ammonia to nitrite which is the form of nitrogen readily available to plants. Therefore, it is important to understand the community structure of ammonia oxidizers as they play a very important function in soil.

Previous studies [22] using soils from the same area as in this study showed a shift in microbial community structure between a grass prairie and a cultivated field when biomass $\mathrm{C}$, phosphatase, and substrate utilization were measured. We used phospholipids to assess microbial biomass and community structure from the four eastern Washington State soils because PLFAs are rapidly turned over and thus represent the current living community, both quantitatively and qualitatively. DGGE of the 16S rDNA fragment amplified directly from the soil DNA using general bacterial primers was used to quantify the level of bacterial community diversity. Diversity of ammonia-oxidizing bacteria of the $\beta$ subdivision of the class proteobacteria was also analyzed using the DGGE technique. We confirmed the results of this assay by cloning and sequencing a partial stretch of genes that encodes the active-site polypeptide of ammonia monooxygenase (amoA). Therefore, our objective was to use molecular biology techniques to examine the influence of different management practices and precipitation along a transect of agronomic zones on components of the microbial community and how these factors influence the diversity of microbial population at the functional level.

\section{Materials and methods}

\subsection{Site selection and sampling}

Soil samples $(0-10 \mathrm{~cm})$ were collected along a transect from representative sites in Columbia and Adams counties in eastern Washington State. Farming practices were comprised mainly of small grains with minimal tillage (MT), conservation reserve program (CRP), legumes with no-tillage (NT), and dry-land and irrigation systems with conventional tillage $(\mathrm{CT})($ Table 1). The Natural Resources Inventory database of primary sampling unit for Washington was used [23], along with county surveys, to select sites from the two counties, based upon the different agricultural-management histories, current farming practices, and annual precipitation. To locate each of the four sampling sites, a Magellan NAV 5000 pro Global Positioning System was used. One sample was taken from each of the sampling sites and four additional satellite samples were taken at distances of $100 \mathrm{~m}$ in the four cardinal compass directions. The satellite samples were collected to account for local variability, in a $100-\mathrm{m}$ radius around the center sample. All samples were kept in sealed plastic bags and mixed immediately. Samples were then placed on dry ice and stored at $-70^{\circ} \mathrm{C}$ prior to DNA extraction.

\subsection{Phospholipid extraction, separation, and analysis}

Soil samples ( $5 \mathrm{~g}, n=5)$ were extracted by using the modified method of Bligh and Dyer as described by Petersen and Klug [24]. The total lipid extract was fractionated into glyco-, neutral, and polar lipids [25]. The polarlipid fraction was transesterified with a mild alkali to recover the PLFA as methyl esters in hexane. The PLFAs were separated, quantified and identified by GC-flame ion-

Table 1

Chemical and biological properties of sites studied*

\begin{tabular}{|c|c|c|c|c|c|c|c|}
\hline $\begin{array}{l}\text { Location and } \\
\text { site description }\end{array}$ & $\begin{array}{l}\text { Soil type; tillage; } \\
\text { and crops }\end{array}$ & $\begin{array}{l}\text { Precipitation } \\
(\mathrm{mm})\end{array}$ & $\begin{array}{l}\text { Organic carbon } \\
\left(\mathrm{g} \mathrm{kg}^{-1}\right)\end{array}$ & $\begin{array}{l}\mathrm{CEC} \\
\left(\mathrm{cmol}^{(+)}\right. \\
\left.\mathrm{kg}^{-1}\right)\end{array}$ & $\begin{array}{l}\text { Biomass } \\
\left(\mathrm{nmol} \mathrm{g}^{-1}\right. \\
\text { dry wt) }\end{array}$ & $\begin{array}{l}\text { No. of } \\
\text { bands }\end{array}$ & $\begin{array}{l}\text { Dehydrogenase } \\
\left(\mu \mathrm{g} \mathrm{g}^{-1} \text { dry }\right. \\
\text { wt } \mathrm{h}^{-1}\end{array}$ \\
\hline Columbia County (MT) & $\begin{array}{l}\text { Palouse silt loam; MT; } \\
\text { small grains }\end{array}$ & $>400$ & $30.2 \mathrm{a}$ & $24.6 \mathrm{a}$ & $61.2 \mathrm{ab}$ & 17 & $2.75 \mathrm{a}$ \\
\hline Columbia County (CRP) & $\begin{array}{l}\text { Walla Walla silt loam; CRP; } \\
\text { grass cover }\end{array}$ & $350-400$ & $12.4 \mathrm{~b}$ & $14.1 \mathrm{~b}$ & $60.8 \mathrm{ab}$ & 18 & $2.85 \mathrm{a}$ \\
\hline Columbia County (NT) & Couse silt loam; NT; alfalfa & $250-300$ & $20.8 \mathrm{ab}$ & $10.9 \mathrm{bc}$ & $67.6 \mathrm{a}$ & 20 & $2.61 \mathrm{a}$ \\
\hline Adams County $(\mathrm{CT})$ & Shano silt loam; CT; potato & under 200 & $5.4 \mathrm{c}$ & $6.1 \mathrm{c}$ & $56.3 \mathrm{~b}$ & 17 & $1.50 \mathrm{~b}$ \\
\hline
\end{tabular}

* Means for organic carbon, cation exchange capacity (CEC), biomass, and dehydrogenase activities within a column followed by the same letters are not significantly different from each other using the Duncan Waller-K-ratio t-test procedure $(p=0.05)$. 
ization detection [26]. Samples were run for $38 \mathrm{~min}$, long enough for fatty acids with up to 28 carbons to elute from the column. The system consisted of a GC (HP6980-Hewlett Packard, Wilmington, DE, USA) with a flame ionization detector and HP3365 ChemStation software.

\subsection{Fatty acid nomenclature}

The suffixes '-c' for cis and '-t' for trans refer to geometric isomers. The prefixes 'i-', 'a-', and 'me-' refer to iso-, anteisomethyl, and mid-chain methyl branching, respectively, with cyclopropyl rings indicated by 'cy' [27].

\subsection{DNA extraction, PCR primers, and DGGE analysis}

Total bacterial community DNA was extracted by placing about $500 \mathrm{mg}$ of soil in FastPrep tubes (BIO 101, Vista, CA, USA) containing lysing matrix. Isolation of total DNA was accomplished with a FastPrep DNA isolation kit according to the manufacturer's protocol (BIO 101). PCR was first performed using 20-80 ng template DNA with the primers, PRBA338f and PRUN518r, located at the V3 region of the $16 \mathrm{~S}$ rRNA genes of bacterioplankton [28], to assess bacterial community diversity. PCR mixtures for the bacterial 16S rDNA sequence amplification contained $10 \mathrm{pmol}$ of each primer, $4 \mu \mathrm{g}$ of bovine serum albumin, and sterile distilled water in a final volume of $25 \mu \mathrm{l}$. The PCR cycles used for amplification were as follows: $92^{\circ} \mathrm{C}$ for $2 \mathrm{~min}$, followed by 30 cycles of $92^{\circ} \mathrm{C}$ for $1 \mathrm{~min}, 55^{\circ} \mathrm{C}$ for $30 \mathrm{~s}, 72^{\circ} \mathrm{C}$ for $1 \mathrm{~min}$, and a single final extension at $72^{\circ} \mathrm{C}$ for $6 \mathrm{~min}$.

DGGE was performed with $8 \%$ (w/v) acrylamide gels containing a linear chemical gradient ranging from 30 to $70 \%$ denaturant with $100 \%$ defined as $7 \mathrm{M}$ urea and $40 \%$ formamide. Gels were run for $3 \mathrm{~h}$ at $200 \mathrm{~V}$ with a Dcode Universal Mutation System (Bio-Rad Laboratories, Hercules, CA, USA). DNA was visualized after ethidium bromide staining by UV transillumination and photographed with a Polaroid camara.

\subsection{DGGE, blotting, and sequencing of ammonia oxidizers}

To determine the diversity of ammonia-oxidizing bacteria in the four soils, a nested PCR assay was first performed with bacterial-specific primers 27f and 1492r [29]. A second PCR assay was performed with the CTO 189fGC and CTO 645r [30]. The first PCR assay was performed with $50 \mathrm{ng}$ of template DNA using the following parameters: $94^{\circ} \mathrm{C}$ for $2 \mathrm{~min}$, followed by 30 cycles of $92^{\circ} \mathrm{C}$ for $30 \mathrm{~s}, 55^{\circ} \mathrm{C}$ for $60 \mathrm{~s}$, and $75 \mathrm{~s}$ at $72^{\circ} \mathrm{C}$ (with the time increasing $1 \mathrm{~s} /$ cycle), and a final single extension at $72^{\circ} \mathrm{C}$ for $5 \mathrm{~min}$ with a reaction volume of $25 \mu \mathrm{l}$. Products with the expected size of $1.5 \mathrm{~kb}$ were excised from the gel, melted by heating at $65^{\circ} \mathrm{C}$ for $5 \mathrm{~min}$ and $1 \mu \mathrm{l}$ was used as template in a second PCR with the CTO primers. PCR products recovered with $\mathrm{CTO}$ primers were subjected to
DGGE as described above, except a gradient of 30-60 denaturant was used with a run time of $4 \mathrm{~h}$.

A second PCR was performed with the CTO primers but without the GC-clamp for Southern blot analysis. Aliquots $(10 \mu \mathrm{l})$ of the CTO PCR products were separated in $1 \%$ agarose gels. The DNA fragments were transferred to a nylon membrane [31] and were fixed by UV cross-linking. Hybridization analyses were conducted by using the oligonucleotide probes (Nsp436 for all Nitrosospira and Nmo254a for all Nitrosomonas) and hybridization conditions described by Stephens et al. [32]. Probe labeling and immunological detection were done by random primed incorporation of DIG Oligonucleotide 3 '-end labeling kit (Boehringer Mannheim, Bedford, MA, USA) as recommended by the manufacturer.

A third PCR was performed with amoA primers that target a partial stretch of genes that encode the activesite polypeptide of amoA [33]. Amplification was performed in a total volume of $50 \mu \mathrm{l}$. The reaction conditions were $94^{\circ} \mathrm{C}$ for $2 \mathrm{~min}$, followed by 30 cycles of $92^{\circ} \mathrm{C}$ for $60 \mathrm{~s}, 55^{\circ} \mathrm{C}$ for $60 \mathrm{~s}$, and $68^{\circ} \mathrm{C}$ for $45 \mathrm{~s}$, and a final single extension at $72^{\circ} \mathrm{C}$ for 5 min with 10 pmol of each primer. PCR products were gel-purified and extracted with QiaexII gel extraction kit (Qiagen, Valencia, CA, USA). Purified fragments were cloned with the pGEM-T Easy vector (Promega, Madison, WI, USA) and transformed into Escherichia coli JM109. Plasmid isolations were performed using the Qiagen plasmid mini kit as described by the manufacturer. For each soil, 40 clones with the correct size of insert were selected and amplified rDNA restriction analysis (ARDRA) technique was performed to assess the genetic diversity of ammonia-oxidizing bacteria from the different soils [34]. After PCR reamplification of the clones with the vector primers M13 and T7, $5 \mu$ of the PCR products was digested with the restriction endonuclease HinfI and analyzed by separation of fragments on a $2 \%$ low-melting agarose gel in Tris-acetate-EDTA. Representative clones from each digestive pattern were selected for sequencing and data analyses. The purified DNA was sequenced with the ABI PRISM Dye Terminator Cycle Sequencing kit with AmpliTaq DNA Polymerase, FS (Perkin Elmer).

\subsection{Phylogenetic analysis}

Sequence analyses were done using the BLAST database (National Center for Biotechnology Information, www.ncbi.nlm.nih.gov). Partial amo $A$ gene sequences were aligned with parts from the complete amo $A$ gene sequences of ammonia-oxidizing bacteria obtained from the BLAST gene bank. Sequence alignments were performed using the PILEUP program from the University of California-Riverside Genetics Computer Group (GCG programs). Matrices of evolutionary distances were computed using the Phylip program with the Jukes-Cantor model [35]. Phylogenetic trees were constructed and 
checked by bootstrap analysis (100 data sets) using the program SEQBOOT. Bootstrap values represent the frequency of resampling that supports a specific branching pattern.

\subsection{Statistical analysis of PLFA and DGGE bands}

Data analyses were performed using SAS [36]. Means and standard deviations for the individual fatty acids in triplicate-sample PLFA profiles were determined to compare the composition of the PLFA profile in samples from different sites. Average mole percent ratios of selected fatty acids were used to estimate microbial biomass using selected PLFAs as biomarkers. Principle component analysis (PCA) was used to compare PLFA profiles among the four sites and the data were presented as a $3 \mathrm{D}$ plot for better understanding of the relationship. PCA explains the variance-covariance structure through a few linear combinations of the original variance (PLFA) with coefficients equal to the eigenvectors of the correlation matrix [37].

DNA fingerprints obtained from the 16S rDNA DGGE banding patterns on the gels were photographed and digitized using ImageMaster Labscan (Amersham-Pharmacia Biotech, Uppsala, Sweden). The lanes were normalized to contain the same amount of total signal after background subtraction. The gel images were straightened and aligned using ImageMaster 1D Elite 3.01 (Amersham-Pharmacia Biotech, Uppsala, Sweden) and analyzed to give a densitometric curve for each gel. Band positions were converted to $R_{\mathrm{f}}$ values between 0 and 1 and profile similarity was

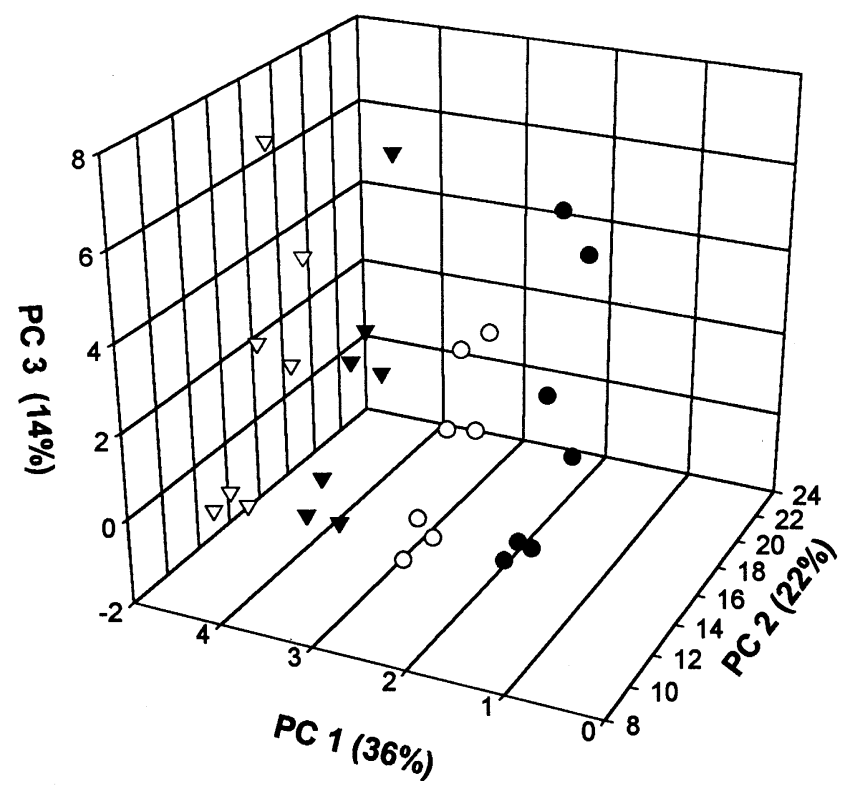

Fig. 1. PCA of microbial community structure from four soils in eastern Washington State as determined by their PLFA profiles. ๑: MT with small grain and annual rainfall greater than $400 \mathrm{~mm}$, O: CRP (annual rainfall of $350-400 \mathrm{~mm}$ ), $\mathbf{\nabla}$ : NT under alfalfa pasture and annual rainfall between $250-300, \Delta$ : CT with potato, and annual rainfall below $200 \mathrm{~mm}$. PCA was conducted with 49 PLFAs that explained $72 \%$ of the total variance in the first three dimensions. calculated by determining Dice's coefficient for the total number of lane patterns. Dendrograms were constructed by using the unweighted pair group method with mathematical averages (UPGMA). Dice's similarity coefficients were generated, converted into $x / y$ line plots, and transferred to Excel files. Community similarities based on peak areas from the Excel files for the different bacterial groups (16S rDNA bands) were analyzed by correspondence analysis (CANACO 4.0, Microcomputer Power, Ithaca, NY, USA) to generate an ordination diagram as described by Ibekwe et al. [25].

\section{Results and discussion}

\subsection{Chemical and biological properties of soils}

Results of biological and chemical data from the four soils are presented in Table 1. Organic carbon and CEC were significantly higher in the Palouse silt loam soil with MT. These parameters were lowest in the Shano silt loam soil with CT. The Shano soil also had the lowest amount of annual precipitation in all of the sites studied. There were no $\mathrm{pH}$ differences among the four soils. No significant differences were found in dehydrogenase or biomass for the MT, CRP, or NT soils. However, the CT soil had significantly lower dehydrogenase and biomass (Table 1).

\subsection{PLFA analysis for microbial community structure and biomass}

Principal component analyses of PLFA data of soil communities (Fig. 1) were conducted to determine the microbial community structure of the four soils. PCA was conducted with 49 PLFAs that were present in the soil samples. The PCA plot (Fig. 1) for the four soil microbial communities accounted for $36 \%$ of the variance on the first component, while the second component accounted for $22 \%$, and the third component accounted for $14 \%$. This explained $72 \%$ of the total variance in the first three dimensions of the plot. PCA of the samples revealed separation of the four soils into four distinct clusters (Fig. 1). The MT, CRP, and NT soils formed distinct clusters along principle components (PCs) 1 and 2, while the CT soil clustered along PC3. All analyses were done using the correlation matrix and the Kaiser's rule [37], which states that variables with eigenvalues greater than 1 should be used for further analysis. A second PCA was conducted on matrices with fewer PLFAs. Eighteen PLFAs with the most significant contributions to the PCA $(r=0.55)$ were selected. The $3 \mathrm{D}$ plot constructed from the reduced matrix did not show different clustering (data not shown). PLFAs contributing most significantly to each of the principal component scores were the same for both the reduced data set (18 PLFAs) and the unreduced set (49 PLFAs). Branched, monounsaturated, and cyclopropane PLFAs 
were heavily weighted on PC1 (a15:0, i15:0, i16:0,

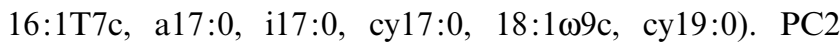
and PC3 were heavily weighted by straight-chain PLFA $(\mathrm{PC} 2=12: 0$, a13:0, 15:0, 17:0, 20:0; $\mathrm{PC} 3=14: 0$ and 16:0). Most of the fatty acids in PC1 are primarily of bacterial origin [38]. The clusters obtained from the soil communities indicate differences in the biomarker compositions in the four soils.

PLFA content in the four soils, as determined by microbial biomass per gram of dry weight, showed marked significant variations ranging from $67.6 \mathrm{nmol} \mathrm{g}^{-1}$ dry wt in the Couse silt loam soil with NT to $56.3 \mathrm{nmol} \mathrm{g}^{-1}$ dry wt in the Shano silt loam soil. The variation in biomass composition from the four soils was in agreement with the clusters obtained in Fig. 1. In a complex environment such as soil, the different fatty acid compositions can be divided into different metabolic groups for proper understanding of the community composition (Fig. 2). Hydroxy PLFA compositions in the four soils were lower than cyclopropane PLFA, and these PLFAs are characteristic of Gram-negative bacteria [38]. Monounsaturated fatty acids showed some differences among the four sites, but this did not follow any pattern associated with precipitation. Straight-chain PLFAs had the highest mole percent concentration in all the samples, with 16:0 having the highest percent concentration. Branched PLFAs, characteristic of Gram-positive bacteria $[39,40]$, were about three- to fivefold higher in soils than the hydroxy group. The polyunsaturated PLFAs, mostly 18:2 w6c, characteristic of fungi [41], were higher in the MT and CT soils.

PLFA composition and biomass observed in this study provided some evidence of how microbial communities are shaped due to the influence of different agricultural practices and environmental conditions. These results showed that there were significant differences in microbial biomass among the four soils. For example, total PLFA contents

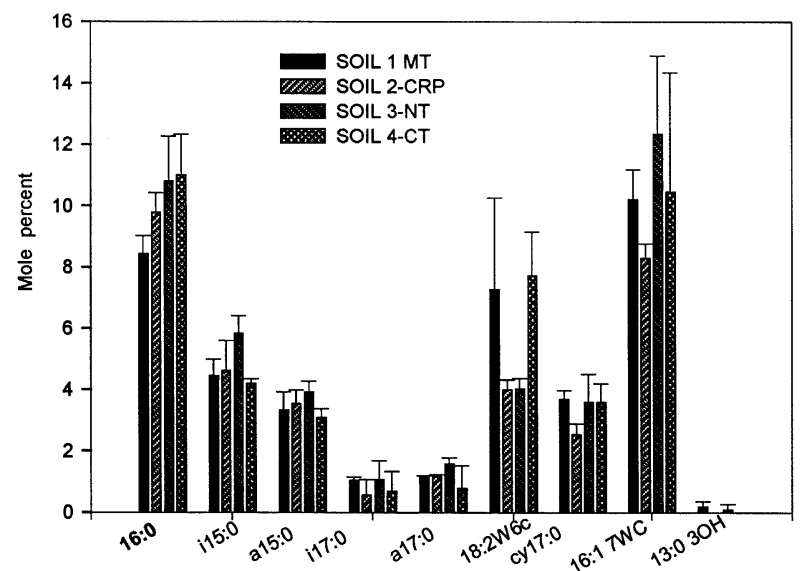

Fig. 2. Average mole percent concentration of some indicator PLFAs from four eastern Washington State soils: MT with small grains and annual rainfall greater than $400 \mathrm{~mm}$; CRP and annual rainfall of 350 $400 \mathrm{~mm}$; NT with alfalfa and annual rainfall between 250 and 300; CT with potato, and annual rainfall below $200 \mathrm{~mm}$. Bars represent standard errors of values averaged across replicates of each fatty acid.
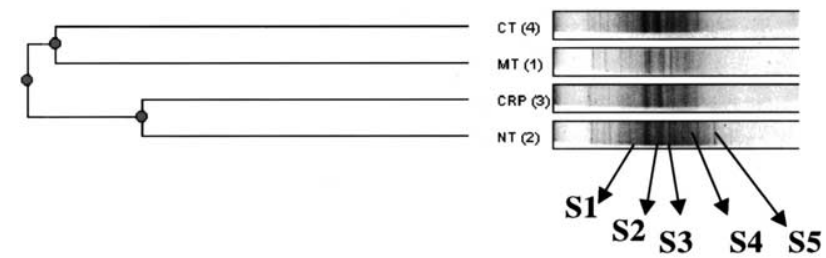

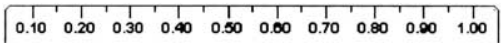

Fig. 3. DGGE analysis of $16 \mathrm{~S}$ rDNA PCR amplification products obtained with the bacteria primers from pooled soil samples from different locations at the sampling site. Lanes 1, 2, 3, and 4 were under MT, CRP, NT, and CT, respectively. Soil samples were collected from the center of the plot and four additional satellite samples were collected at distance $100-\mathrm{m}$ radius around the center sample. Soil samples were mixed and community DNA extracted.

which reflect active microbial biomass $[42,43]$ declined significantly from $67.6 \mathrm{nmol} \mathrm{g}^{-1}$ dry wt in Couse silt loam soil under NT and alfalfa to $56.3 \mathrm{nmol} \mathrm{g}^{-1}$ dry wt in Shano silt loam soil under CT and potato. Organic carbon was four times greater in the Couse silt loam than the Shano soil, and this factor has been shown to have strong correlation with microbial biomass carbon [2]. Biomass from PLFA may be a strong indicator of bacterial composition since it represents all microbial biomass and indicates active living microbial components. Biomass from phospholipid has been found to be more representative of the microbial biomass than that obtained from the chloroform-fumigation method $[5,44]$.

\subsection{Analysis of microbial community diversity by DGGE}

Examination of the band profile in the DGGE gel revealed that the communities consisted of five predominant bacterial DGGE groups that were present in all the soils and some minor groups that co-migrated in the DGGE gel. To compare DGGE patterns from the four soils, Dice's indices were determined for comparisons of all profiles, and UPGMA was used to create a dendrogram describing pattern similarities (Fig. 3). The bands in the DGGE profile correspond to the 16S rDNA fragments that differ in nucleotide sequences. This represents the dominant microbial population in the four soils pooled from the center sample and the four satellite samples. Based on the analysis of the DGGE banding patterns, 17, 18, 20, and 17 major bands were observed from $\mathrm{Pa}-$ louse, Walla Walla, Couse, and Shona silt loam soils, respectively (Table 1).

Eichner et al. [45] described the community structure in activated sludge and noted that the number and intensity of bands did not equal the number and abundance of species within the microbial community due to features of $16 \mathrm{~S}$ rDNA-based phylogeny and bias inherent to PCR amplification from complex template mixtures. The reasons for most of the limitations are that DGGE banding patterns are subjected to PCR bias due to DNA ex- 


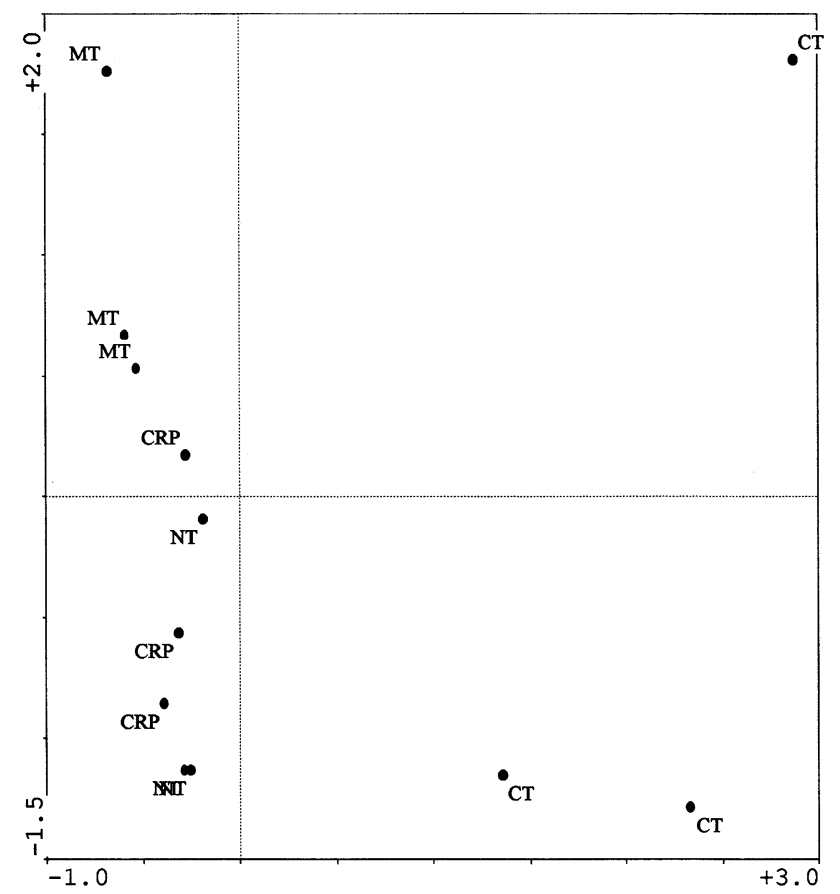

Fig. 4. Correspondence analysis of microbial communities generated by the analysis of DGGE $16 \mathrm{~S}$ rDNA PCR patterns from four eastern Washington State soils.

traction methods, potential preferential amplification, and the formation of chimera [46]. Other problems may result from one organism producing more than one DGGE band because of multiple, heterogeneous rRNA operons [4749]. Also, for some phylogenetic groups of bacteria, $16 \mathrm{~S}$ rDNA sequences do not allow discrimination between species, so one DGGE band may represent several species with identical rDNA sequences [50].

In a community DNA mixture such as soil, the maximum number of different rDNA fragments separated by DGGE may be vastly underestimated. Torsvik et al. [51] found that there might be as many as $10^{4}$ different genomes present in soil samples. This shows that DGGE can not separate all of the 16S rDNA fragments obtained from soil microorganisms, but only the dominant species [15]. Therefore, the banding patterns obtained in this study reflect the most abundant rDNA types in the community.

The second method for the calculation of community diversity was done by first calculating the similarities of three sampling points from each soil by correspondence analysis (Fig. 4). The statistical procedure uses matrix algebra to describe banding pattern data in a multidimensional space. The data are graphed using eigenvectors that locate within the communities a set of coordinates for factors that describe the data set, with corresponding eigenvalues that describe the amount of variation that is explained by each factor. Sixty seven percent of the variance in the community structure was explained by three factors, with factor one explaining $38 \%$ and factor two
$19 \%$. The difference between the communities with respect to the first and the second eigenvectors was the distance between the two points representing the communities on the ordination diagram. A comparison of the distances showed that the microbial communities from the CT soils had the most dissimilar structure (Fig. 4). The three CT samples were separated by about 1 standard deviation on the $x$-axis and 3 standard deviations on the $y$-axis (Fig. 4). The communities associated with NT, MT, and CRP were separated on the average among and within themselves with less than 0.5 standard deviation (Fig. 4).

The use of PLFA and DGGE methods provided useful information on the composition of soil microbial communities. PLFA analysis of soil microbial community structure by PCA (Fig. 1) and the analysis of DGGE patterns (Figs. 3 and 4) revealed a common pattern of clustering from the four soils. From the three analyses, NT and CRP soils clustered closer to each other than CT and MT soils. These results suggest that soil microbial community responds more to management than precipitation. Based on a previous study [22] and this study it is quite clear that microbial community structure is very sensitive to changes in soil management. Therefore, microbial community structure sets the potential for functional response to management changes, which in turn affect soil processes.

\subsection{Diversity of ammonia-oxidizing bacteria recovered from soils}

The relationship between community structure and function was further explored by examining the functional gene encoding the $\alpha$ subunit of amoA. Results obtained from the DGGE analysis of ammonia-oxidizing bacteria were very reproducible across the four soils (Fig. 5). DGGE patterns from the sampling points showed two similar dominant bands from the four sites that were closely related to Nitrosospira. Previous results from se-

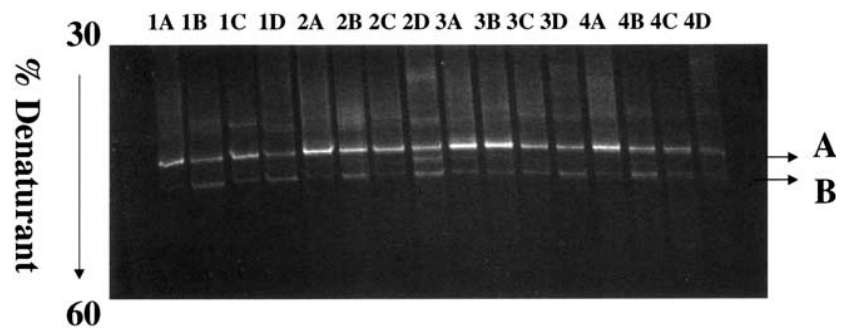

Fig. 5. DGGE band pattern of $16 \mathrm{~S}$ rDNA PCR amplification products obtained with the ammonia-oxidizing primers (26) and community DNA. DGGE gels were stained with ethidium bromide and photographed under UV illumination. Lanes: 1A, 1B, 1C, 1D (MT soil); 2A, 2B, 2C, 2D (CRP soil); 3A, 3B, 3C, 3D (NT soil); 4A, 4B, 4C, and 4D (CT soil). PCR products from soils $1,2,3$, and 4 in triplicate samples and sample D from pooled samples after mixing samples A, B, and C together. The arrows on the right indicate the location of the two dominant bands closely related to Nitrosospira-like sequences. 
quencing $[30,32,52,53]$ using the same primers as in this study showed that the two bands contained sequences that were closely related to Nitrosospira-like sequence of the $\beta$ subdivision ammonia oxidizers. These authors also stated that bands one and two may be doublets with a slight difference in sequence composition. The DGGE patterns obtained from our four soils and the satellite samples were very similar, even though soils one and four were tilled plots with different crops (Fig. 5). In our study, two dominant bands co-migrated in all of the soils, irrespective of management practices or precipitation. This suggests that there is a high degree of stability of ammonia oxidizers in most agricultural soils. Bruns et al. [53] observed similar DGGE patterns in agricultural soils with different crops over a 2-year period.

To confirm whether Nitrosospira-like sequences of $\beta$-subdivision ammonia oxidizers were the dominant genera in these soils, PCR amplification of the soil samples with CTO primers were used for Southern hybridization with non-radioactive biotin-labeled oligonucleotide probes Nsp436 for all Nitrosospira and Nmo254a for all Nitrosomonas (data not shown). This confirmed the identity of the PCR products. Strong hybridization signals were obtained from the four soils with probe Nsp436 and very weak signals obtained with the Nmo254a probe. Hybridization patterns indicated that bands from DNA of the four soils were derived mainly from Nitrosospira DNA, suggesting that Nitrosospira is more dominant in these agricultural soils than Nitrosomonas.

To determine the genetic heterogeneity of ammonia oxidizers, the gene encoding the $\alpha$ subunit of amo $A$ was selected as a functional marker for ammonia oxidizers. PCR amplification of the four soils produced DNA fragments of the expected size (ca. $491 \mathrm{bp}$ ). The diversity of recovered rDNA PCR fragments in the soil samples was examined by comparative ARDRA. ARDRA with HinfI digestion revealed a total of six major banding patterns from the four soils (data not shown). Soil 3, under alfalfa and NT, had 5 ARDRA banding patterns. Soil 2, under CRP had two ARDRA banding patterns. Both soil 1 (after harvest of small grain under minimum tillage) and soil 4 (under potato and conservation tillage) had four ARDRA banding patterns. Soils 1 and 4 are from areas with the highest and lowest annual precipitation, respectively. These observations suggest that precipitation rate may not have any significant effect on the natural population of ammonia oxidizers. However, management and crop types may play a more significant role. Two cloned representatives from each pattern and from each soil were selected for sequence analysis. BLAST searches of the GenBank database confirmed that all sequenced clones represented amo $A$-like sequences. The identity values for the amo $A$ sequences from these soil samples varied between 93.0 and $100 \%$. Two of the cloned sequences were identified as Nitrosospira briensis and $N$. briensis C-57 (Fig. 6) and the other four were unidentified bacterium

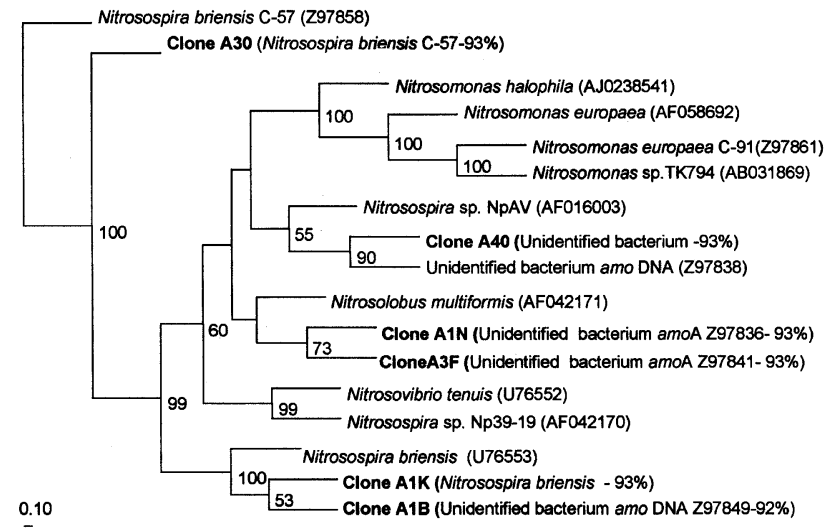

Fig. 6. Phylogenetic tree constructed for partial amoA gene stretches belonging to ammonia-oxidizing bacteria derived from soil samples based on 450 nucleotide positions. A neighbor-joining analysis with JukesCantor correction and bootstrap support was performed on the amo $A$ gene sequences and reference sequences gathered from the Ribosomal Database Project by using the Phylip suite of programs. Bootstrap values are given at nodes when they exceeded $50 \%$ and refer to the clusters to the right of each number. Scale bar, $10 \%$ estimated change.

amo $A$ sequences of the Nitrosospira genus as described by Rothauwe et al. [33].

The use of the functional gene target of amo $A$ sequences provided an example of diversity of ammonia oxidizers that is very crucial in soil-management assessment. NT soil with alfalfa had the highest diversity (five) of amo $\mathrm{A}$ sequences, while CRP had the lowest (two). One possible explanation for the high diversity in the NT plot may be the continuous presence of the rhizosphere from alfalfa plants that provided a special niche for the proliferation of different strains of ammonia oxidizers compared to the CRP that was covered with grass. The CT and MT soils had four amoA sequences each. This finding is in agreement with Bruns et al. [53] who found a greater genetic diversity of autotrophic ammonia-oxidizer sequences in soils from native, undisturbed soils than in tilled soils. $N$. briensis clone AIK and unidentified amoA clone A1N sequences were found only in soils 1 and 4 (Fig. 6). These soils were under some form of tillage regime and nitrogen fertilization. This suggests that these strains were either more adapted to these soils or were below detection limit for this technique in the other soils. On the other hand, $N$. briensis $\mathrm{C}-57$ clone $\mathrm{A} 3 \mathrm{O}$ and unidentified amo A clone $\mathrm{A} 4 \mathrm{O}$ sequences were present in all the four soils, and may be more abundant in most agricultural soils. The presence of only two clones (A4O, A3O) in the CRP soil suggests that this soil contained very low numbers of ammonia oxidizers.

In this study, we have provided information on microbial community structure from four soils with contrasting soil management and environmental conditions. The use of biochemical and molecular biology tools to assess the impact of management indicated that NT practices improved the biological condition of the soil in eastern Washington State compared to CT practice. Two indica- 
tors to explain this conclusion are (1) the high microbial biomass as determined by PLFA analysis and (2) the greater diversity of amo $A$ sequences associated with the NT soil. The use of different molecular methods for the analyses of environmental and management effects is a new approach that will greatly assist in understanding changes in soil health over small time scales since microbiological parameters may be the first to indicate changes or stress.

\section{References}

[1] Scow, K.M., Bruns, M.A., Graham, K., Bossio, D., Schwartz, E. (1998) Development of indices of microbial community structure for soil quality assessment. In: Soil quality in the California environment (Zabel, A. and Sposito, G., Eds.), pp. 110-123. Kearney Foundation of Soil Science Annual Report of Research Projects 1997-98

[2] Doran, J.W. and Parkin, T.B. (1994) Defining and assessing soil quality. In: Defining soil quality for a sustainable environment (Doran, J.W., Coleman, D.C., Bezdicek, D.F. and Steward, B.A., Eds.), pp. 3-21. SSSAJ Special Publ. 35, Madison, WI.

[3] Tisdall, J.M. (1991) Fungal hyphae and structural stability of soil. Aust. J. Soil Res. 29, 729-743.

[4] Parkinson, D. and Coleman, D.C. (1991) Microbial communities, activities, and biomass. Agric. Ecosyst. Environ. 34, 3-33.

[5] Jordan, D., Kremer, R.J., Bergfield, W.A., Kim, K.Y. and Cacnio, V.N. (1995) Evaluation of microbial methods as potential indicators of soil quality in historical agricultural fields. Biol. Fertil. Soils 19, 297-302.

[6] Turco, R.F., Kennedy, A.C. and Jawson, M.D. (1994) Microbial indicators of soil quality. In: Defining soil quality for a sustainable environment (Doran, J.W., Coleman, D.C., Bezdicek, D.F. and Steward, B.A., Eds.), pp. 73-90. SSSAJ Special Publ. 35, Madison, WI.

[7] Alexander, M. (1977) Introduction to Soil Microbiology. John Wiley and Sons, New York.

[8] Findlay, R.H. (1996) The use of phospholipid fatty acids to determine microbial community structure. In: Molecular Microbial Ecology Manual (Akkermans, A.D.L., Van Elsas, J.D. and de Bruijn, F., Eds.), pp. 4.1.11-4.1.17. Kluwer Academic Publ., Dordrecht.

[9] Amann, R.L., Ludwig, W. and Schleifer, K.H. (1995) Phylogenetic identification and in situ detection of individual microbial cells without cultivation. Microbiol. Rev. 59, 143-169.

[10] Balkwill, D.L., Leach, F.L., Wilson, T.J., McNabb, J.F. and White, D.C. (1988) Equivalence of microbial biomass measures based on membrane lipid and cell wall components, adenosine triphosphate, and direct counts in the subsurface aquifer sediments. Microbiol. Ecol. 16, 73-84.

[11] Ringelberg, D.B., Davis, J.D., Smith, G.A., Pfiffner, S.M., Nichols, P.D., Nickels, J.S., Henson, J.M., Wilson, J.T., Yates, M., Kampbell, D.H., Reed, H.W., Stocksdale, T.T. and White, D.C. (1988) Validation of signature phospholipid fatty acids biomarkers for alkalineutilizing bacteria in soil and subsurface aquifer materials. FEMS Microbiol. Ecol. 62, 39-50.

[12] Rajendran, N., Matsuda, O., Imamura, N. and Urushigawa, Y. (1992) Variation in microbial biomass and community in the sediments of eutrophic bays as described by phospholipid ester-linked fatty acids. Appl. Environ. Microbiol. 58, 562-571.

[13] Zelles, L., Bai, Q.Y., Beck, T. and Beese, F. (1992) Signature fatty acids in phospholipids and lipopolysaccharides as indicators of microbial biomass and community structure in agricultural soils. Soil Biol. Biochem. 24, 317-323.

[14] Zelles, L., Rackwitz, L.R., Bai, Q.Y., Beck, T. and Beese, F. (1995) Discrimination of microbial diversity by fatty acid profiles of phos- pholipids and lipopolysaccharides in differently cultivated soils. Plant Soil. 170, 115-122.

[15] Muyzer, G.E., De Waal, C. and Uitterlinden, A.G. (1993) Profiling of complex microbial populations by denaturing gradient gel electrophoresis analysis of PCR-amplified genes coding for 16S rRNA. Appl. Environ. Microbiol. 59, 695-700.

[16] Ferris, M.J., Muyzer, G. and Ward, D.M. (1996) Denaturing gradient gel electrophorisis profiles of $16 \mathrm{~S}$ rRNA-defined populations inhabiting a hot spring microbial mat community. Appl. Environ. Microbiol. 62, 1045-1050.

[17] Brunk, C.F., Avaniss-Aghajani, E. and Brunk, C.A. (1996) A computer analysis of primer and probe hybridization potential with bacterial small-subunit rRNA sequences. Appl. Environ. Microbiol. 62, 872-879.

[18] Dunbar, J., Takala, S., Burns, S.M., Davis, J.A. and Kuske, C.R. (1999) Levels of bacterial community diversity in four arid soils compared by cultivation and 16S rDNA gene cloning. Appl. Environ. Microbiol. 65, 1662-1669.

[19] Clement, B.G., Kehl, L.E., DeBord, K.L. and Kitts, C.L. (1998) Terminal restriction fragment patterns (TRFPs), a rapid, PCR-based method for the comparison of complex bacterial communities. J. Microbiol. Methods 31, 135-142.

[20] Borneman, J., Skrock, P.W., O’Sullivan, K.M., Palus, J.A., Rumjanet, N.G., Jansen, J.L., Nienhuis, J. and Triplett, E.W. (1996) Molecular microbial diversity of an agricultural soil in Wisconsin. Appl. Environ. Microbiol. 62, 1935-1943.

[21] Borneman, J. and Triplett, E.W. (1997) Molecular microbial diversity in soils from eastern Amazonia: evidence of unusual microorganisms and microbial population shifts associated with deforestation. Appl. Environ. Microbiol. 63, 2647-2653.

[22] Kennedy, A.C. and Smith, L.K. (1995) Soil microbial diversity and the sustainability of agricultural soils. Plant Soil. 170, 75-86.

[23] USDA-NRCS (1999) National Resources Inventory: www.nhq.nrcs.usda/NRI.

[24] Petersen, S.O. and Klug, M.J. (1994) Effects of sieving, storage, and incubation temperature on the phospholipid fatty acid profiles of a soil microbial community. Appl. Environ. Microbiol. 60, 2421-2430.

[25] Ibekwe, A.M., Papiernik, S.K., Gan, J., Yates, S.R., Yang, C.-H. and Crowley, D.E. (2001) Impact of fumigants on soil microbial communities. Appl. Environ. Microbiol. 67, 3245-3257.

[26] Macnaughton, S.J., Stephen, J.R., Venosa, A.D., Davis, G.A., Chang, Y.-J. and White, D.C. (1999) Microbial population changes during bioremediation of an experimental oil spill. Appl. Environ. Microbiol. 65, 3566-3574.

[27] Kates, M. (1986) Techniques in Lipidology: Isolation, Analysis and Identification of Lipids, 2nd edn. Elsevier Press, Amsterdam.

[28] Øvreas, L., Forney, L., Daae, F.L. and Torsvik, T. (1997) Distribution of bacterioplankton in meromictic Lake Saelenvannet, as determined by denaturing gradient gel electrophoresis of PCR-amplified gene fragments coding for 16S rRNA. Appl. Environ. Microbiol. 63, 3367-3373.

[29] Lane, D. (1991) 16S/23S sequencing. In: Nucleic acid techniques in bacterial systematics (Stackebrandt, E. and Goodfellow, M., Eds.), pp. 115-175. John Wiley and Sons, New York.

[30] Kowalchuk, G.A., Stephens, J.R., Boer, W.D., Prosser, J.I., Embley, T.M. and Woldendorp, J.W. (1997) Analysis of ammonia-oxidizing bacteria of the $\beta$ subdivision of the class Proteobacteria in coastal sand dunes by denaturing gradient gel electrophoresis and sequencing of PCR-amplified 16S rDNA fragments. Appl. Environ. Microbiol. 63, 1489-1497.

[31] Sambrook, J., Fritch, E.F. and Maniatis, T. (1989) Molecular Cloning: A Laboratory Manual, 2nd edn. Cold Spring Harbor Laboratory, Cold Spring Harbor, NY.

[32] Stephens, J.R., Kowalchuk, G.A., Bruns, M.A., McCaig, A.E., Phillips, C.J., Embley, T.M. and Prosser, J.I. (1998) Analysis of $\beta$-subgroup proteobacterial ammonia oxidizer populations in soil by dena- 
turing gradient gel electrophoresis analysis and hierarchical phylogenetic probing. Appl. Environ. Microbiol. 64, 2958-2965.

[33] Rotthauwe, J.H., Witzel, K.P. and Liesack, W. (1997) The ammonia monooxygenase structural gene amoA as a functional marker: molecular fine-scale analysis of natural ammonia-oxidizing populations. Appl. Environ. Microbiol. 63, 4704-4712.

[34] Stephen, J.R., Chang, Y.-J., Macnaughton, S.J., Kowalchuk, S.J., Leung, K.T., Flemming, C.A. and White, D.C. (1999) Effect of toxic metals on indigenous soil-subgroup proteobacterium ammonia oxidizer community structure and protection against toxicity by inoculated metal-resistant bacteria. Appl. Environ. Microbiol. 65, 95-101.

[35] Islam, M.S., Hasan, M.K., Miah, M.A., Sur, G.C., Felsenstein, A., Venkatesan, M., Sack, R.B. and Albert, M.J. (1993) Use of the polymerase chain reaction and fluorescent-antibody methods for detecting viable but nonculturable Shigella dysenteriae type 1 in laboratory microcosms. Appl. Environ. Microbiol. 59, 536-540.

[36] SAS Institute (1988) Users Guide: Statistic Version 6. Statistical Analytical Inst., Carey, NC.

[37] Jolliffe, I.T. (1986) Principal Component Analysis. Springer-Verlag, New York.

[38] Wilkinson, S.G. (1988) Gram-negative bacteria. In: Microbial Lipids, Vol. 1. (Ratledge, C. and Wilkinson, S.G., Eds.), pp. 299-488. Academic Press, London.

[39] Ratledge, C. and Wilkinson, S.G. (1988) Microbial Lipids, Vol. 1. Academic Press, New York.

[40] White, D.C. (1983) Analysis of microorganisms in terms of quantity and activity in natural environments. Soc. Gen. Microbial. Symp. 34, 37-66.

[41] Federle, T.W. (1986) Microbial distribution in soil - new techniques. In: Perspective in Microbial Ecology (Megusar, F. and Gantar, M., Eds.), pp. 493-498. Slovene Society for Microbiology, Ljubljana.

[42] Frostegård, Å., Tunlid, A. and Bååth, E. (1996) Changes in microbial community structure during long-term incubation in soils experimentally contaminated with metals. Soil Biol. Biochem. 28, 55-63.

[43] Tunlid, A. and White, D.C. (1992) Biochemical analysis of biomass, community structure, nutritional status, and metabolic activity of microbial community in soil. In: Soil Biochemistry, Vol. 7 (Stotzky, G. and Bollag, J.-M., Eds.), pp. 229-262. Marcel Dekker, Inc., New York.
[44] Petersen, S.O., Henriksen, K., Blackman, T.H. and King, G.M. (1991) A comparison of phospholipid and chloroform fumigation analyses for biomass in soil: potential and limitations. FEMS Microbiol. Ecol. 85, 2257-2268.

[45] Eichner, C.A., Erb, R.W., Timmis, K.N. and Wagner-Döbler, I. (1999) Thermal gradient gel electrophoresis analysis of bioprotection from pollutant shocks in the activated sludge microbial community. Appl. Environ. Microbiol. 65, 102-109.

[46] Wintzingerode, F.V., Göbel, U.B. and Stackebrandt, E. (1997) Determination of microbial diversity in environmental samples: pitfalls of PCR-based rRNA analysis. FEMS Microbiol. Rev. 21, 213-229.

[47] Cilia, V., Lafay, B. and Christen, R. (1996) Sequence heterogeneities among $16 \mathrm{~S}$ ribosomal RNA sequences, and their effect on phylogenetic analyses at the species level. Mol. Biol. Evol. 13, 451-461.

[48] Nübel, U., Engelen, B., Felske, A., Snaidr, A., Wieshuber, A., Amann, R., Ludwig, W. and Backhaus, H. (1996) Sequence heterogeneties of genes encoding 16S rRNAs in Paenibacillus polymyxa detected by temperature gradient gel electrophoresis. J. Bacteriol. $178,5636-5643$.

[49] Rainey, F.A., Ward-Rainey, N.L., Janssen, P.H., Hippe, H. and Stackebr, E. (1996) Clostridium paradoxum DSM 7308T contains multiple 16S rRNA genes with heterogeneous intervening sequences. Microbiology 142, 2087-2095.

[50] Vallaeys, T., Topp, E., Muyzer, G., Macheret, V., Laguerre, G., Rigaud, A. and Soulas, G. (1997) Evaluation of denaturing gradient gel electrophoresis in the detection of $16 \mathrm{~S}$ rDNA sequence variation in rhizobia and methanotrophs. FEMS Microbiol. Ecol. 24, 285-289.

[51] Torsvik, V., Goksoyr, J. and Daae, F.L. (1990) High diversity in DNA of soil bacteria. Appl. Environ. Microbiol. 56, 782-787.

[52] Kowalchuk, G.A., Naoumenko, Z.S., Derikx, P.J.L., Felske, S., Stephens, J.R. and Arkhipchenko, I.A. (1999) Molecular analysis of ammonia-oxidizing bacteria of the $\beta$ subdivision of the class Proteobacteria in compost and composted materials. Appl. Environ. Microbiol. 65, 396-403.

[53] Bruns, M.A., Stephens, J.R., Kowalchuk, G.A., Prosser, J.I. and Paul, E.A. (1999) Comparative diversity of ammonia oxidizer 16S rRNA gene sequences in native, tilled, and successional soils. Appl. Environ. Microbiol. 65, 2994-3000. 